\title{
Implementation of Intrapreunership Education Leadership In SD IT Al-Ihsan Baleendah Bandung
}

\author{
Alamsyah Nurseha', Neni Nadiroti Muslihah², Ejen Jenal Mutaqin ${ }^{3}$, Lutfi Asy'ari ${ }^{4}$ \\ ${ }^{1}$ STIT Al-Ihsan Baleendah \\ 2,3,4 Institut Pendidikan Indonesia (IPI) Garut \\ alamsyahnurseha@gmail.com
}

Article History

accepted 05/11/2020

approved 10/11/2020

published 01/02/2021

\begin{abstract}
Educational leadership is the ability to drive the implementation of education, so that educational goals can be achieved effectively and efficiently. In fostering fraternity and being responsible for making decisions, developing, and maintaining the existence of an organization, the leadership function must play a role. Competition between SDITs in Bandung Regency, especially in Baleendah District, will have an impact on how the principal should be the captain in carrying out school leadership, as has been done by SDIT Al-Ihsan Baleendah. The focus of this research is the implementation of intrapreneurship educational leadership at SDIT Al-Ihsan Baleendah. This study aims to capture the leadership implementation carried out by the principal at SDIT Al-Ihsan Baleendah. This type of research is a qualitative descriptive study. In the data collection technique, various techniques were used in this study, namely interviews, observation and documentation. The data analysis procedure used in this study was qualitative analysis. Based on the findings from the research results, it is concluded that the implementation of intrapreneurship educational leadership at SDIT Al-Ihsan Baleendah can be implemented and has a positive impact on the implementation of SDIT Al-Ihsan Baleendah.
\end{abstract}

Keywords: leadership, intrapreneurship, SD-IT

\begin{abstract}
Abstrak
Kepemimpinan pendidikan merupakan kemampuan menggerakkan pelaksanaan pendidikan, sehingga tujuan pendidikan dapat tercapai secara efektif dan efisien. Dalam pembinaan persaudaraan dan bertanggung jawab dalam mengambil keputusan, mengembangkan, dan mempertahankan eksistensi organisasi fungsi kepemimpinan harus berperan. Persaingan antar SDIT di Kabupaten Bandung, khususnya di Kecamatan Baleendah akan berdampak pada bagaimana kepala sekolah harus menjadi nakhoda dalam menjalankan kepemimpinan sekolah, seperti halnya yang dilakukan oleh SDIT AI-Ihsan Baleendah. Fokus penelitian ini adalah implementasi kepemimpinan pendidikan intrapreneurship di SDIT Al-Ihsan Baleendah. Penelitian ini bertujuan untuk memotret implementasi kepemimpinan yang dilakukan oleh kepala sekolah di SDIT Al-Ihsan Baleendah. Jenis penelitian ini merupakan penelitian deskriptif kualitatif. Dalam teknik pengumpulan data pada penelitian ini dipergunakan berbagai teknik, yaitu wawancara, observasi, dan dokumentasi. Prosedur analisis data yang digunakan dalam penelitian ini analisis kualitatif. Berdasarkan temuan dari hasil penelitian, disimpulkan implementasi kepemimpinan pendidikan intrapreneurship di SDIT Al-Ihsan Baleendah mampu diimplementasikan dan berdampak positif pada penyelenggaraan SDIT Al-Ihsan Baleendah.
\end{abstract}

Kata kunci: Kepemimpinan, Intrapreneurship, SD-IT

Social, Humanities, and Education Studies (SHEs): Conference Series https://jurnal.uns.ac.id/shes

p-ISSN 2620-9284

e-ISSN 2620-9292 


\section{PENDAHULUAN}

Undang-Undang RI Nomor 20 Tahun 2003 Tentang Sistem Pendidikan Nasional dalam Pasal 40 Ayat (2) menyatakan bahwa pendidik dan tenaga kependidikan berkewajiban memberi teladan dan menjaga nama baik lembaga, profesi, dan kedudukan sesuai dengan kepercayaan yang diberikan kepadanya, mempunyai komitmen secara profesional untuk meningkatkan mutu pendidikan serta mampu menciptakan suasana pendidikan yang bermakna, menyenangkan, kreatif, dinamis dan dialogis (Ritonga,2019). Mengingat fungsi kepala sekolah memiliki peranan yang sangat penting dan strategis dalam meningkatkan kualitas pelayanan pendidikan. Dalam membentuk peribadi manusia, pendidikan menjadi factor utamanya. Secara normative, baik buruk manusia ditentukan oleh peranan dari Pendidikan.

Dengannya, capaian pendidikan di sekolah harus mampu diakomodir oleh kemampuan menggerakkan berbagai factor yang mempengaruhinya, yakni kepemimpinan pendidikan. Pengembangan seluruh potensi sekolah, diantaranya pendidik, tenaga kependidikan, siswa, sarana dan prasarana, kurikulum guna mencapai prestasi akademik dan non akademik secara maksimal oleh kepala sekolah/madrasah sebagai pemimpin. Selain itu, kemampuan berperan sebagai pemimpin efektif yang memfokuskan kepada pengembangan instruksional, organisasional, staf, layanan kepada siswa, serta hubungan dan komunikasi dengan masyarakat dibutuhkan sebagai tuntutan kepala sekolah.

Covey mengemukakan tujuh kebiasaan pemimpin yang tidak efektif yaitu: bersikap reaktif yaitu tidak percayadiri dan menyalahkan orang lain, bekerja tanpa mengacu pada tujuan yang jelas, melakukan hal-hal yang lebih mendesak terlebih dahulu, berfikir menang - kalah, minta dipahami terlebih dahulu, bila anda tidak bisa menang berkompromi, takut pada perubahan dan menolak perbahan. Kepemimpinan yang sukses melibatkan kemampuan pengambilan keputusan yang berorientasi tujuan sebagai basis utama (Marshal-Mies, et al. 2000). Pemimpin juga harus memiliki kemampuan dalam menjalin hubungan untuk menata struktur organisasi dan mengelola perubahan sesuai dengan aspek situasional dengan berdasarkan pada tujuan (Larsson, 2010).

Fungsi utama pemimpin pendidikan adalah kelompok untuk belajar memutuskan dan bekerja, antara lain:

1. Pemimpin membantu terciptanya suasana persaudaraan, kerjasama dengan penuh rasa kebebasan

2. Pemimpin membantu kelompok untuk mengorganisir diri yaitu ikut serta dalam memberikan rangsangan dan bantuan kepada kelompok dalam menetapkan dan memjelaskan tujuan

3. Pemimpin membantu kelompok dalam menetapkan prosedur kerja, yaitu membantu kelompok dalam menganalisis situasi untuk kemudian menetapkan prosedur mana yang paling efektif dan efisien

4. Pemimpin bertanggungjawab dalam mengambil keputusan bersama dengan kelompok

5. Pemimpin bertanggung jawab dalam mengembangkan dan mempertahankan eksistensi organisasi

Berdasarkan Peraturan Menteri Pendidikan Nasional No, 13 Tahun 2007 seorang Kepala Sekolah harus memiliki kompetensi kepribadian, kompetensi social, kompetensi manajerial, dan kompetensi kewirausahaan. Kompetensi manajerial Kepala sekolah tidak bisa terlepas dari kompetensi kewirausahaan yang merupakan salah satu sikap utama dari seorang pemimpin pendidikan.

Berikut ini profil Kepala sekolah yang memiliki kemampuan manajemen dan kepemimpinan pendidikan intrapreuner yang diharapkan mampu meningkatkan keberhasilan sekolah. 
a. Kemampuan manajemen dan kepemimpinan intrapreneur Kepala Sekolah dalam menetapkan arah.

b. Kemampuan manajemen dan kepemimpinn Intrapreneur kepala sekolah dalam mengorganisasikan sekolah.

c. Kemampuan manajemen dan kepemimpinan Intrapreneur dalam memotivasi dan membangun kreativitas.

d. Kemampuan manajemen dan kepemimpinan Intrapreneur kepala sekolah dalam komunikasi.

e. Kemampuan manajemen dan kepemimpinan Intrapreneur dalam mengambil keputusan.

Kemampuan manajemen dan kepemimpinan pendidikan sangat penting dimiliki Kepala Sekolah yang berkaitan dengan Continual Success. Mengingat Sekolah adalah lembaga pendidikan yang mendidik para siswa untuk masa depan, sikap kewirausahaan harus dijadikan landasan dalam manajemen dan kepemimpinan pendidikan, yaitu manajemen dan kepemimpinan pendidikan Intrapreneur yang berkualitas. Sikap Intrapreneurship dalam kemampuan manajemen dan kepemimpinan Kepala Sekolah mampu memberikan nilai masa depan yang kreatif.

Konsekuensinya, seorang pemimpin yang berkualitas dituntut untuk dapat secara bijaksana mengambil keputusan dalam penyelesaian masalah terkait bidang kependidikan. Bijaksana dalam arti keputusan diambil secara kritis dan kreatif dengan mempertimbangkan keberagaman kepentingan berbagai pihak terkait sebagai upaya terjaminnya kualitas pendidikan. Hal ini selaras dengan idealisme bahwa lingkungan internal yang positif dan pembinaan oleh pemimpin merupakan pencetus utama tercapainya tujuan secara bersama (Carson, 2002). Oleh karena itu, sebaiknya seorang pemimpin pendidikan memiliki: 1) pengetahuan mengenai berbagai hal yang terkait dengan operasionalisasi sekolah, baik yang bersifat umum maupun yang khusus, 2) kemampuan menentukan kriteria yang digunakan untuk mengevaluasi keberhasilan, 3) Kemampuan dalam merencanakan dan memantau berbagai proses yang berlangsung di sekolah, menyusun berbagai alternatif tindak lanjut dan memutuskan langkah yang terbaik untuk meningkatkan kualitas pendidikan. Gambaran ketiga kemampuan tersebut dapat diperoleh melalui asesmen terhadap kemampuan metakognitif seorang kepala sekolah.

Saat ini dengan adanya berbagai perubahan baik yang menyangkut kebijakan maupun tuntutan masyarakat terhadap kualitas pendidikan yang berdampak kepada kualitas lulusan, maka sangat diperlukan figure lain dari kepemimpinan pendidikan yang dapat membawa kepada kemajuan, yaitu dengan kepemimpinan intrapreneur. Keberhasilan kepemimpinan pendidikan seseorang tergantung pada kecakapannya mengubah motivasi dan "mind sef" orang-orang yang dipimpinnya. Seorang pemimpin harus dapat mengubah pola fikir orang-orang yang ada dalam lembaga pendidikan sesuai dengan pola fikirnya dan mengubah motivasinya yang ekstrinsik menjadi instrinsik.

Kepala sekolah intrapreneur senantiasa berani dalam hadapi berbagai resiko dalam perhitungannya. Artinya kematangan menterjemahkan berbagai resiko menjadi berbagai program kegiatan dalam menyelenggarakan pendidikan. Minimal hal ini dilakukan untuk mengukur dari sudut pandang kekuatan, kelemahan, keuntungan, dan kerugian.

Toleransi terhadap kesalahan pun menjadi indicator kepala sekolah intrepreneur. Dengannya perlu belajar dari berbagai kesalahan, sehingga tidak mengulang lagi kesalahan tersebut di masa yang akan datang. Kepala sekolah intrapreneur toleran terhadap kesalahan yang dilakukan oleh guru maupun karyawan sekolah. Namun tidak berhenti dalam bentuk tolerasi saja, tetapi kepala sekolah intrapreneur akan membimbing dan memotivasi guru dan karyawan sekolah untuk berbuat yang terbaik dan tidak mengulang kesalahan yang sama di masa selanjutnya (Lasem, 1992:17), 
Selain itu, Lasem (1992:18) menjelaskan, kepekaan intuisi terhadap peluang bisnis ini muncul karena kepala sekolah intrapreneur senantiasa peka melihat makna di balik sebuah peristiwa. Walaupun sekolah sebagai lembaga non profit, dalam hal bisnis jelas yang harus difahami ialah bagaimana perspektif pelanggan yang menentukan kualitas pelayanan pendidikan. Sekolah Dasar Islam Terpadu Al-Ihsan Baleendah, menjadi salah satu yang paling terkenal dan eksis di daerah Baleendah, Kabupaten Bandung. Dalam beberapa tahun terakhir SDIT Al-Ihsan Baleendah mengalami banyak kemajuan. Hal ini diindikasikan dengan adanya pola kepemimpinan yang efektif dan efisien di SDIT Al-Ihsan Baleendah. Dengan alasan inilah peneliti ingin lebih mengetahui tentang kepemimpinan pendidikan interpreneurship di SDIT Al-Ihsan Baleendah dalam penyelenggaraan pendidikan.

\section{METODE}

Pendekatan fenomenologi dengan jenis penelitian deskriptif kualitatif, merupakan prosedur penelitian dengan data deskriptif berupa kata tertulis atau lisan dari orang-orang dan perilaku yang diamati. Peneliti melihat dan memahami subyek dan obyek penelitian berdasarkan fakta seadanya untuk mengumpulkan data, menyajikan informasi kemudian mendeskripsikan keadaan "Implementasi Kepemimpinan Pendidikan Intrapreneurship di SDIT Al-Ihsan Baleendah Bandung" kemudian menarik kesimpulan berdasarkan ketentuan yang ditetapkan.

Objek dalam penelitian ini adalah SDIT Al-Ihsan Baleendah yang difokuskan pada pola kepemimpinan pendidikan intrapreneurship. Subjek penelitiannya adalah sumber tempat kita memperoleh keterangan penelitan. Menurut Suharsimi Arikunto subjek penelitian adalah benda, hal atau orang tempat data untuk variable melihat, dan yang dipermasalahkan, dalam penelitian ini adalah Kepala Sekolah, beberapa Guru dan beberapa orang karyawan (tenaga kependidikan).

Teknik observasi partisipatif, peneliti langsung mengamati yang terjadi di SDIT Al-Ihsan Baleendah Kabupaten Bandung untuk mengamati dan memahami serta mencatat berbagai aspek yang berkaitan dengan kepemimpinan pendidikan intrapreneurship. Pedoman wawancara yang digunakan berupa garis besar permasalahan yang ditanyakan. Selebihnya peneliti mengumpulkan berbagai dokumentasi pendukung analisa. Hal tersebut di atas mempermudah peneliti melakukan analisis data melalui proses reduksi data, penyajian data dan menarik kesimpulan.

\section{HASIL DAN PEMBAHASAN}

Meskipun saat ini persaingan dalam bidang pendidikan cukup ketat, baik dari segi jumlah sekolah yang semakin banyak sampai dengan persaingan dalam hal biaya pendidikan yang ditawarkan setiap sekolahpun cukup bersaing. Namun jumlah peserta didik di SDIT Al-Ihsan Baleendah setiap tahun tetap stabil. Hal ini dapat berarti bahwa tingkat kepercayaan masyarakat terhadap hasil pendidikan disekolah ini cukup baik.

Dari hasil wawancara bersama responden, Kepala Sekolah telah mampu menerapkan kepemimpinan Management by Walking About atau manajemen dengan melaksanakan. Begitu pula menurut Kepala SDIT AI-Ihsan Baleendah, keinginan untuk unggul tidak bisa dikomunikasikan dari balik meja. MBWA menekankan pentingnya kehadiran pemimpin dan pemahaman atau pandangan mereka terhadap karyawan dan proses institusi.

Maka kepemimpinan yang berkualitas pasti mementingkan komunikasi visi dan nilai-nilai institusi kepada pihak-pihak lain, serta berbaur dengan para staf dan pelanggan. Kualitas pemimpin pendidikan membutuhkan perspektif-perspektif berikut ini: 
1) Visi dan simbol-simbol. Pemimpin harus mengkomunikasikan nilai-nilai institusi kepada para staf, para pelajar dan kepada komunitas yang lebih luas. Dari hasil observasi, SDIT Al-Ihsan Baleendah dalam beberapa programnya menghadirkan pertemuan periodic yang lebih intens mengkomunikasikan capaian program dalam rangka mengukur capaian visi dan misi sekolah.

2) Kualitas kepemimpinan dibutuhkan bagi mutu sebuah instansi. Dalam hal ini, peneliti menemukan hasil wawancara bersama salah satu guru yang menyebutkan bahwa kepala sekolah dalam hal pelayanan berkualitas kepada pelanggan, telah menjadi misi yang harus dicapai oleh SDIT Al-Ihsan Baleendah. Salah satunya ialah penerapan mutu pelayanan untuk mengejar prestasi dan kepuasan siswa dalam hafalan Al-Quran.

3) 'Untuk para pelajar' istilah ini diistilahkan dengan perspektif kepuasan pelanggan dalam pendidikan. Institusi memiliki fokus yang jelas terhadap pelanggan utama. Sama halnya dengan point ke dua, Kepala Sekolah dengan tegas menjadikan pelayanan berkualitas dalam misi sekolahnya. Hal tersebut bukan hanya pada unsur pelayanan belajar mengajar. Namun dibuktikan dengan pelayanan bermutu dari perspektif pengadaan sarana prasarana yang jelas mendukung pelayanan pendidikan di SDIT Al-Ihsan Baleendah.

4) Otonomi, eksprimentasi dan antisipasi terhadap kegagalan. Pemimpin pendidikan harus melakukan inovasi diantara staf-stafnya dan bersiapsiap mengantisifasi kegagalan yang mengiringi inovasi tersebut. Dalam hal ini, peneliti menemukan korelasi dari penyelenggaraan program pertemuan harian dalam rangka mengukur capaian program. Hal ini menjadi ukuran bagaimana Kepala Sekolah mampu mengantisipasi kegagalan atau kekurangan pelayanan pendidikannya di SDIT Al-Ihsan Baleendah.

5) Menciptakan rasa kekeluargaan. Pemimpin harus menciptakan rasa kekeluargaan diantara para pelajar, orang tua, guru dan staf institusi. Beberapa hasil observasi memberikan gambaran bahwa Kepala SDIT Al-Ihsan Baleendah memberikan pelayanan prima kepada seluruh stakeholdernya. Baik kepada institusi eksternal, maupun konsumen internal dan eksternalnya. Hal ini dibuktikan dengan beberapa pertemuan yang diselenggarakan benar-benar mengangkat nilai-nilai kekeluargaan baik kepada pelajar maupun orang tua siswa.

6) Ketulusan, kesabaran, semangat, intensitas, dan antusiasme. Sifat-sifat tersebut merupakan mutu personal esensial yang dibutuhkan pemimpin lembaga pendidikan. Berbagai inovasi berbentuk program menjadi gambaran bagi peneliti, yang juga didukung dari hasil wawancara bahwa berbagai program kerja yang diselenggarakan, Kepala SDIT AlIhsan Baleendah melakukannya dengan penuh ketulusan, kesabaran, semangat, intensitas dan antusiasme yang tinggi.

Dalam penyelenggaraan Pendidikan secara berkualitas yang berlandaskan kepemimpinan yang efektif dan Intrapreneur maka rambu rambu harus dibuat dalam mengecek kualitas tersebut yaitu secara mendasar penilaian kinerja kepala sekolah mengacu kepada Peraturan Menteri Pendidikan Nasional Nomor 13 Tahun 2007. Berdasarkan acuan tersebut di atas maka arah penilaian difokuskan kepada hal-hal sebagai berikut:

1. Kemampuan mengambil resiko

2. Kreatif dan inovatif

3. Kemampuan memulai kerja dan penyelesaian kerja 
4. Ketercapaian target pekerjaan

5. Berfikiran positif

6. Menetapkan arah organisasi

7. Mengorganisasikan Sekolah

8. Membangun kreatifitas

9. Komunikasi

10. Mengambil keputusan

Dari point-point tersebut, peneliti menemukan berbagai korelasi antara program kerja di SDIT AI-Ihsan Baleendah dengan hasil wawancana dan observasi. Bagaimana Kepala SDIT Al-Ihsan Baleendah, telah banyak memberikan teladan dalam kemampuan mengambil resiko yang memperhitungkan berbagai kekuatan, kelemahan, peluang, atau tantangan di SDIT Al-Ihsan Baleendah.

Begitu pula pada akhirnya, terdapat gambaran yang menunjukan bahwa kepemimpinan pendidikan intrapreneurship yang dijalankan oleh Kepala SDIT AI-Ihsan Baleendah mampu menghasilkan berbagai program kreatif dan inovatif. Mengingat di tahun ke dua ini, SDIT Al-Ihsan Baleendah langsung menyelenggarakan pendidikannya di tengah pandemic Covid 19.

Potret capaian kinerja dengan mudah diukur setiap hari, karena program meeting/rapat harian selalu membahas capaian program. Hal ini jelas menjadi indikasi yang mendominasi implementasi kepemimpinan pendidikan intrapreneurship di lingkungan SDIT Al-Ihsan Baleendah.

Sama halnya dalam hal ini menjadi potret arah organisasi SDIT Al-lhsan Baleendah yang senantiasa, diukur dari sudut pandang kualitas dan kuantitas. SDIT Al-Ihsan Baleendah memperlihatkan komitmen pelayanan prima terhadap konsumennya. Maka, kreatifitas juga komunikasi yang dibangun menjadi beberapa dasar kuat untuk Kepala SDIT AI-Ihsan Baleendah mengambil keputusan yang harus disepakati dan dijalankan hingga dievaluasi.

Dalam rangka menghadapi berbagai resiko, terlebih penyelenggaraan pendidikan di era pandemic covid 19, SDIT Al-Ihsan Baleendah telah mampu melaluinya dengan baik. Jelas hal ini menjadi indikasi utama bagaimana sudut pandang kepemimpinan yang dijalankan. Kepemimpinan Intrapreneurship yang menjadi focus penelitian ini memberikan gambaran positif bagi para penyelenggara pendidikan, sesuai dengan implementasi Kepemimpinan Intrapreneurship di SDIT AIIhsan Baleendah.

Kepemimpinan pendidikan intrapreneurship yang dilakukan SDIT Al-Ihsan Baleendah adalah hal yang dibutuhkan oleh lembaga, mengingat perjalanan penyelenggaraan pendidikan pada tahun-tahun awal pendirian membutuhkan implementasi Kepala Sekolah yang lebih efektif dan efisien. Maka, Kepala SDIT AIIhsan Baleendah dalam hal ini telah menunjukan capaian prestasi SDIT Al-Ihsan Baleendah dengan mengimplementasikan kepemimpinan pendidikan intrapreneurship.

\section{SIMPULAN}

Berdasarkan temuan hasil penelitian dan pembahasan maka hasil penelitian ini dapat disimpulkan bahwa implementasi kepemimpinan pendidikan intrapreneurship di SDIT Al-Ihsan Baleendah terlaksana sesuai tahapan dengan ideal. Baik berdasarkan nilai-nilai leadership, maupun berdasarkan tata aturan yang berlaku. Kepemimpinan pendidikan intrapreneurship yang dilakukan SDIT Al-Ihsan Baleendah adalah hal yang dibutuhkan oleh lembaga, mengingat perjalanan penyelenggaraan pendidikan pada tahun-tahun awal pendirian membutuhkan implementasi Kepala Sekolah yang lebih efektif dan efisien. Maka, Kepala SDIT Al-Ihsan Baleendah dalam hal ini telah menunjukan capaian prestasi SDIT Al-Ihsan Baleendah dengan mengimplementasikan kepemimpinan pendidikan intrapreneurship. Dengannya, kepemimpinan intrapreneur 
merupakan solusi dalam menghadapi situasi yang banyak mengalami perubahan baik yang berkaitan dengan peraturan perundang-undangan maupun kebutuha masyarakat. $\mathrm{Hal}$ ini pun sangat dibutuhkan demi terselenggaranya pendidikan yang berkualitas sehingga dapat menghasilkan lulusan yang berkualitas dan di tengah persaingan penyelenggara pendidikan yang tinggi.

\section{DAFTAR PUSTAKA}

Data SDIT Al-Ihsan Baleendah, Tahun 2020.

Arikunto, Suharsimi. (2013). Manajemen Penelitian. Jakarta: Rineka Cipta.

Fikar, Ritonga, Mursal. Strategi Pimpinan Wilayah Muhammadiyah dalam Melakukan Perekrutan Guru di SMA Muhammadiyah se Kota Padang. Ruhama: Islamic Education Journal, Vol 1, No.2 (2019): Oktober 2019. p-ISSN :2615-2304

Hadi, Sutrisno. (1986). Statistik II. Yogyakarta: UGM Press.

Leni, Candra. Kepemimpinan Transformasional dalam Peningkatan Mutu Pendidikan Anak Usia Dini. Al-Tanzim: Jurnal Manajemen Pendidikan Islam. Vol. 03 No. 02 (2019) : 13-24. E-ISSN: 2549-5720 P-ISSN: 2549-3663

Marshall-Mies. et al. (2000). Development and Evaluation of Cognitive and Metacognitif Measures for Predicting Leadership Potential. Leadership Quarterly. 11 (1):135153.

Mumuh Muhtarom, 2018. Implementasi Kepemimpinan dan Manajemen dalam Lembaga Pendidikan. Tatar Sunda, Jurnal Diklat Keagamaan, Volume XII Nomor 33.

Lexi J. Moleong. (2014). Metodologi Penelitian Kualitatif. Bandung: PT Remaja Rosdakarya.

Tatang, M. Amirin. (1990). Menyusun Rencana Penelitian. Jakarta: Rajawali Press.

Sugiyono. (2014). Metode Penelitian Pendidikan. Jakarta: Rineka Cipta. 